Dinamika Sosial Budaya, Vol 22, No. 2, Desember 2020, pp 272-283

p-ISSN: 1410-9859\& e-ISSN: 2580-8524

http://journals.usm.ac.id/index.php/jdsb

\title{
KESALAHAN PENGUCAPAN BAHASA INGGRIS PADA MAHASISWA (ERROR PRONUNCIATION)
}

\section{Devy Angga Gunantar}

Fakultas Teknologi Hasil Pertanian, Universitas Semarang angga.gunantar@gmail.com

\section{Stefani Dewi Rosaria, Hetty Catur Ellyawati}

Fakultas Hukumstefani@usm.ac.id, Fakultas Teknologi Informasi dan Komunikasi catur@usm.ac.id, Universitas Semarang

\begin{abstract}
Abstrak
Penelitian ini merupakan penelitian deskriptif kualitatif yang bertujuan untuk mendeskripsikan kesalahan dalam pengucapan vokal Bahasa Inggris, penyebab terjadinya kesalahan dan jenis kesalahan yang terjadi. Hasil penelitian ini menunjukkan 224 kata yang sering salah diucapkan oleh mahasiswa. Hal ini terjadi karena perbedaan vokal dalam Bahasa Indonesia dan Bahasa Inggris, ada beberapa vokal dalam Bahasa Inggris yang tidak dimilliki oleh Bahasa Indonesia sehingga mahasiswa seringkali menggantinya dengan suara yang mirip dengan Bahasa pertama mereka. Jenis kesalahan yang terjadi dalam pengucapan vokal Bahasa Inggris adalah kesalahan substitusi, kesalahan sisipan, dan kesalahan penghilangan. Kesalahan substitusi terjadi hampir $90 \%$ dari seluruh pengucapan yang dilakukan oleh responden.
\end{abstract}

\begin{abstract}
This is a descriptive qualitative research which aims to describe the error pronunciation of English vowel, the cause of the error, and the type of the error. The result of this research shows there are 224 words which is frequently mispronounce by the students. This is caused by the discrepancies of the vowel words in English and in Indonesian language. Some of the English vowel words do not exist in Indonesian language as a result most of the students replace those words which have similar sounds to their native language. The types of error often happened are the substitution error, inserting error, and omission error. The substitutions error is the highest error made by the students. Nearly $90 \%$ of the mispronounce words is caused by the substitution error.
\end{abstract}

Keywords: error pronunciation; substitution; inserting; omission 
Dinamika Sosial Budaya, Vol 22, No. 2, Desember 2020, pp 272-283

p-ISSN: 1410-9859\& e-ISSN: 2580-8524

http://journals.usm.ac.id/index.php/jdsb

\section{PENDAHULUAN}

Tujuan belajar bahasa Inggris di tingkat perguruan tinggi yaitu untuk menghasilkan lulusan yang profesional, kompeten dan memiliki kemampuan komunikasi berbahasa asing yang baik. Pada tingkat Perguruan Tinggi, khususnya di Universitas Semarang, mata kuliah bahasa Inggris menjadi salah satu mata kuliah yang diwajibkan bagi mahasiswa. Mempelajari bahasa Inggris dalam perkuliahan tentunya mempelajari aspek keterampilan berbahasa diantaranya keterampilan mendengarkan, berbicara, membaca dan menulis. Mahir dalam berbahasa Inggris serta dapat berkomunikasi dengan baik adalah suatu keharusan dan kebutuhan. Beberapa faktor linguistik seperti pengucapan, tata bahasa, leksis, dan idiom harus menjadi tujuan mahasiswa dalam belajar.
Berkaitan dengan komunikasi, komunikasi merupakan proses dua arah. Di satu sisi kita perlu dapat menggunakan bahasa untuk mengekspresikan diri kita kepada orang lain, dan, sebaliknya, kita membutuhkannya untuk memahami apa yang mereka komunikasikan kepada kita (Finch, 2003: 35). Salah satu bagian terpenting yang harus diperhatikan dalam berkomunikasi dengan menggunakan bahasa asing adalah pengucapan. Ketika kita berkomunikasi, suara yang dihasilkan (pelafalan/pengucapan) menjadi bagian terpenting selain tata bahasa.

Keberhasilan berkomunikasi ditandai dari pengucapan/pelafalan yang jelas yang akan membantu pemahaman informasi yang disampaikan dari pembicara ke pendengar atau sebaliknya. Pengucapan adalah bagian penting dari bahasa. Pengucapan sangat penting untuk menghindari kesalahpahaman ketika berkomunikasi. Pengucapan dianggap sebagai persyaratan untuk pengembangan berbicara (Celce-Murcia dan Goodwin dalam Budiasih, 2013: 1) dan keterampilan menyimak (Syafei, 1988: 1). Pengucapan merupakan media utama yang akan menjadi perhatian orang lain saat kita menggunakan bahasa (Stevick dalam Pennington, 1996: 2). Pengucapan juga merupakan media utama untuk menyampaikan informasi tentang diri kita sebagai individu dan sebagai perwakilan dari berbagai kelompok (Pennington, 1996: 2).

Pelafalan bahasa Inggris dianggap cukup sulit untuk orang Indonesia, tidak terkecuali mahasiswa program studi S1 Teknologi Hasil Pertanian, S1 Manajemen, S1 Akuntansi, dan S1 Teknologi Informasi, Universitas Semarang. Dalam beberapa kasus mengalami kesulitan disebabkan oleh fakta bahwa ejaan bahasa yang tidak teratur menjadikan pengucapannya semakin sulit (Syafei, 1988: 1). Huruf kata dalam bahasa 
Dinamika Sosial Budaya, Vol 22, No. 2, Desember 2020, pp 272-283

p-ISSN: 1410-9859\& e-ISSN: 2580-8524

http://journals.usm.ac.id/index.php/jdsb

Inggris tidak mewakili suaranya dan tidak selalu mudah bagi

mahasiswa untuk melihat bagaimana kata bahasa Inggris tersebut harus diucapkan, atau bagaimana kata yang mereka dengar harus ditulis. Di sisi lain, Kelly (2001: 122) menyatakan bahwa dalam bahasa Inggris hubungan antara ejaan dan pengucapan lebih kompleks.

Selain pernyataan di atas, sumber kesulitan pengucapan adalah karena bahasa Inggris sebagai bahasa kedua mungkin bahasa ketiga dari mahasiswa Fakultas Teknologi Pertanian, Manajemen, Akuntansi, dan Teknologi Informasi, Universitas Semarang. Faktanya, para mahasiswa tersebut kebanyakan adalah orang Jawa dan biasanya menggunakan bahasa Jawa sebagai bahasa ibu sementara bahasa Indonesia sebagai bahasa kedua atau bahasa pertama. Latar belakang multi-bahasa ini mengindikasikan bahwa para peserta memiliki lebih dari satu bahasa, dan mereka datang untuk belajar bahasa Inggris (Mathew, 1997: 9).

Bahasa Inggris dan Bahasa Indonesia memiliki 26 huruf dalam mewakili bahasa tertulis tetapi keduanya memiliki cara pengucapan yang berbeda - beda. Di Indonesia ada sekitar 33 suara berbeda yang terdiri dari 23 suara konsonan dan 6 vokal (Muslich, 2008: 94-110) dan 4 diftong (Panitia Pengembangan Bahasa Indonesia, 2016: 4). Pada dasarnya ada hubungan satu sama lain antara ejaan dan pengucapan dalam Bahasa Indonesia. Bunyi hurufnya hampir mirip dan cenderung mudah dipelajari. Bahasa Indonesia adalah lingua franca yang memiliki fitur yang cukup mudah pada sistem bahasanya (Steinhauer, 2000: 175). Sementara dalam bahasa Inggris 44 suara ejaan bahasa Inggris yang berbeda diantaranya 21 huruf konsonan menghasilkan 24 suara dan 5 huruf vokal menghasilkan 20 suara.

Berdasarkan uraian tersebut ada tiga rumusan masalah dalam penelitian ini, yaitu pelafalan suara yang sering terjadi kesalahan dalam mengucapkan vokal Bahasa Inggris, penyebab terjadinya, dan jenis kesalahan dalam melafalkannya.

Kristina et al (2006: 1), mendefinisikan pelafalan sebagai tindakan atau cara pengucapan kata; ucapan. Selain itu, pengucapan adalah produksi suara yang signifikan dalam dua pengertian. Pertama, suara itu penting karena digunakan sebagai bagian dari kode bahasa tertentu. Dalam hal ini, pelafalan adalah sebagai produksi dan penerimaan suara ucapan. Kedua, digunakan untuk mencapai makna dalam konteks penggunaan. Dalam pengertian ini, pengucapan dengan merujuk pada tindakan berbicara (Dalton dan Seidlhofer, 1994: 3). Pengucapan selalu dapat dipelajari dari dua sudut pandang: fonetis dan fonologi (Crystal, 2003: 236).

1. Fonetik

Fonetik adalah ilmu yang mempelajari cara manusia membuat, mengirim, dan menerima suara ucapan. Ini dibagi menjadi tiga cabang utama, sesuai dengan tiga perbedaan,

a) Fonetik artikulatori adalah studi tentang cara organ vokal digunakan untuk menghasilkan suara ucapan.

b) Fonetik akustik adalah studi tentang sifat fisik bunyi ujaran.

c) Fonetik pendengaran adalah studi tentang cara orang memahami suara ucapan.

2. Fonologi

Fonologi adalah studi tentang sistem bahasa dan sifat umum yang ditampilkan oleh sistem. Berbeda dengan fonetik, yang mempelajari semua kemungkinan suara yang dapat dibuat oleh alat vokal manusia, fonologi hanya mempelajari perbedaanperbedaan dalam suara (fonem) yang membuat perbedaan makna dalam bahasa. 
Dinamika Sosial Budaya, Vol 22, No. 2, Desember 2020, pp 272-283

p-ISSN: 1410-9859\& e-ISSN: 2580-8524

http://journals.usm.ac.id/index.php/jdsb

Ketika kita mendengarkan dengan cermat cara orang berbicara bahasa Inggris, kita akan mendengar sedikit perbedaan dalam cara individu mengucapkan suara tertentu.

Dalam bahasa Inggris, tidak ada hubungan antara tulisan dan ejaan. Hal ini menjadi masalah terutama bagi pelajar dalam belajar bahasa Inggris. Faktanya, ada kurang dari 500 kata yang sepenuhnya tidak beraturan (Kelly, 2000: 123) dan beberapa di antaranya adalah kata yang paling sering digunakan (Crystal, 2003: 272). Namun, lebih dari $80 \%$ kata-kata bahasa Inggris dieja menurut pola reguler (Kelly, 2000: 123). Dengan demikian, belajar tentang hubungan yang dapat diprediksi antara ejaan dan pengucapan adalah kunci untuk memahami sistem ejaan (Crystal, 2003: 272).

Dalam pembelajaran bahasa, pembelajar akan selalu menghasilkan kesalahan baik dalam bahasa lisan maupun tulisan. Hal ini terjadi karena bahasa ibu, intralingual, konteks pembelajaran (Brown, 2007: 263), atau faktor lainnya. Studi tentang kesalahan umumnya disebut analisis kesalahan.

1. Definisi Analisis Kesalahan Analisis kesalahan adalah teknik untuk mengidentifikasi, mengklasifikasikan dan secara sistematis menafsirkan bentukbentuk yang tidak dapat diterima yang dihasilkan oleh seseorang yang belajar bahasa asing, menggunakan salah satu prinsip dan prosedur yang disediakan oleh linguistik (Crystal, 1985: 112). Analisis kesalahan adalah jenis studi linguistik komparatif, yang membandingkan bahasa antar mahasiswa pada titik waktu tertentu dengan bahasa target. Idealnya harus dilakukan pada sampel pidato spontan (Corder, 1973: 269.273).

Fokus utama SLA adalah pada kesalahan mahasiswa dan bukti bagaimana kesalahan pelajar dapat memberikan pemahaman tentang proses yang mendasari pembelajaran bahasa kedua atau penguasaan bahasa kedua. Kesalahan mahasiswa adalah jendela ke pikiran pembelajar bahasa (Saville-Troike dalam Fauziati, 2009: 135). Corder in Brown (2007: 257) menyatakan bahwa kesalahan pembelajar sangat penting dalam memberikan bukti kepada peneliti tentang bagaimana bahasa dipelajari atau diperoleh, strategi atau prosedur apa yang digunakan mahasiswa dalam penemuan bahasa. Hal ini juga dapat membantu guru untuk menyusun pelajaran dan latihan perbaikan, koreksi atau pelatihan, yang dapat membantu mahasiswa mengurangi kesalahan mereka (Fauziati, 2009).

\section{METODE}

Rancangan penelitian mengacu pada skema atau rencana yang merupakan seluruh studi penelitian. Dalam melakukan penelitian ini, peneliti menggunakan penelitian deskriptif kualitatif. Penelitian kualitatif menggambarkan fenomena dalam bentuk kata-kata. Penelitian ini termasuk penelitian kualitatif karena Bogdan dan Taylor (dalam Moleong, 2002: 3) mendefinisikan bahwa penelitian kualitatif adalah penelitian yang menghasilkan data deskriptif dalam bentuk kata-kata tertulis atau lisan dari pengamatan orang dan perilaku. Ini menyiratkan bahwa dalam penelitian kualitatif data dan makna muncul secara organik dari konteks penelitian. Penelitian kualitatif telah dilakukan dengan menganalisis data dalam bentuk data nonnumerik. Penelitian kualitatif adalah teknik penelitian yang digunakan untuk mendapatkan wawasan tentang masalah mendasar seputar masalah penelitian dengan mengumpulkan umpan balik nonstatistik dan pendapat yang berakar pada perasaan, sikap, motivasi, nilai, dan persepsi orang sering dari sampel yang disebut juga data lunak.

Metode kualitatif menghasilkan data deskriptif yang sesuai dengan karakteristik 
Dinamika Sosial Budaya, Vol 22, No. 2, Desember 2020, pp 272-283

p-ISSN: 1410-9859\& e-ISSN: 2580-8524

http://journals.usm.ac.id/index.php/jdsb

penelitian kualitatif. Sebagaimana

menunjukkan kemampuan mereka dinyatakan oleh Fraenkel dan Wallen (2006:

12), metode deskriptif bertujuan untuk mendokumentasikan suatu peristiwa, situasi, atau keadaan. Terkait dengan pernyataan di atas, Moloeng (2002: 6) menyatakan bahwa salah satu karakteristik penelitian kualitatif adalah deskriptif.

Sumber data penelitian kualitatif dapat diambil dari perilaku, fenomena, dokumen, arsip, dan lain-lain (Sutopo, 2006: 58). Sumber data dalam penelitian ini adalah peserta sebagai informan. Informan adalah orang yang memberikan informasi tentang sesuatu (Hornby, 1995: 1225). Dalam penelitian ini, peneliti mengumpulkan informasi dari para peserta. Kinerja tes yang direkam, data utama, disediakan oleh para peserta. Kinerja tes yang direkam telah ditranskripsi oleh peneliti untuk menyederhanakan data yang dianalisis.

Dalam penelitian ini, ada sebelas peserta, yaitu mahasiswa semester kedua jurusan Teknologi Hasil Pertanian yang mengikuti tes. Dalam mengambil peserta, peneliti hanya mengambil siswa terdekat sebagai subjek penelitian. Seperti Guilford dan Fructer (dalam Calmorin dan Calmorin, 2008: 104) menggambarkan sebagai sampling insidental yang diterapkan pada sampel-sampel yang diambil karena mereka yang paling tersedia.

Moleong (2002: 6) menyatakan bahwa data deskriptif dikumpulkan dalam bentuk kata atau gambar sebagai pengganti angka. Arikunto (2006: 134), menyatakan bahwa ada lima metode dalam pengumpulan data; wawancara, observasi, tes, kuesioner, dan dokumentasi. Instrumen penelitian dari penelitian ini diperoleh dalam bentuk tes. Tes dilakukan untuk mengetahui di mana kesalahan terjadi dan jenis kesalahan. Tes adalah teknik dalam mengevaluasi kegiatan di mana beberapa item harus dijawab oleh subyek, dan kemudian jawabannya

(berdasarkan skor). Brown (1994: 384), menyatakan bahwa tes adalah metode untuk mengukur pengetahuan kemampuan seseorang, atau kinerja dalam domain yang diberikan. Peneliti mengembangkan tes sebagai tes diagnostik. Tes diagnostik dirancang untuk mendiagnosis aspek tertentu dari suatu bahasa (Brown, 2007: 390).

Dalam mengumpulkan data, peneliti telah memberikan tes dan kuesioner kepada para mahasiswa, para peserta. Tes ini adalah tes lisan. Siswa diminta membaca teks bahasa Inggris hasil narasi mereka sendiri yang sudah dikoreksi struktur kalimatnya sebelumnya. Mereka adalah teks cerita dan teks yang berisi daftar kata-kata bahasa Inggris. Semua tes direkam. Ada dua teks, teks pertama adalah teks cerita, teks kedua adalah daftar kata-kata. Daftar kata berisi 22 poin, setiap poin berisi 4 kata. Teks kedua berisi 20 vokal bahasa Inggris.

Setelah data dikumpulkan, kemudian dianalisis. Teknik yang digunakan untuk menganalisis data adalah analisis kesalahan. Berdasarkan penelitian, peneliti, dalam menganalisis data, menggunakan prosedur berikut menurut Brown (1994):

1. Mengidentifikasi kesalahan.

Dalam mengidentifikasi kesalahan, yang pertama, peneliti harus memilih standar pengucapan bahasa Inggris. Peneliti menggunakan kamus Oxford sebagai buku pegangan untuk pengucapan standar bahasa Inggris. Kedua, mengidentifikasi data yang dikumpulkan apakah itu kesalahan atau kesalahan. Jika itu adalah kesalahan, harus dihilangkan dari analisis. Kemudian, klasifikasi data berdasarkan kesalahan. Langkah terakhir dalam analisis kesalahan adalah menentukan sumber dan jenis kesalahan. 
Dinamika Sosial Budaya, Vol 22, No. 2, Desember 2020, pp 272-283

p-ISSN: 1410-9859\& e-ISSN: 2580-8524

http://journals.usm.ac.id/index.php/jdsb

2. Menjelaskan kesalahan.

Setelah mengidentifikasi kesalahan, langkah selanjutnya adalah menggambarkan kesalahan. Peneliti menggambarkannya secara memadai. Deskripsi ditentukan berdasarkan data dan tes.

\section{HASIL DAN PEMBAHASAN}

Berdasarkan penelitian yang telah dilakukan di Universitas Semarang, peneliti mendapatkan data dari hasil tes speaking yang dilakukan pada 10 mahasiswa semester pertama jurusan manajemen, akuntansi, dan teknologi pertanian yang dilakukan secara acak. Tes tersebut menghasilkan rekaman pengucapan dari setiap mahasiswa. Proses perekaman berlangsung dalam waktu dan situasi yang berbeda. Hal tersebut dikarenakan kondisi peserta yang melakukan pembelajaran secara daring selama musim pandemi sehingga dilakukan melalui rekaman secara mandiri. Dalam menganalisis data, sebagaimana telah dikemukakan pada bab sebelumnya, prosedur yang digunakan peneliti adalah dengan mengidentifikasi kesalahan dan mendeskripsikan kesalahan tersebut.

a. Kesalahan pengucapan vokal dalam berbahasa Inggris

Kesalahan adalah istilah yang mengacu pada kinerja ketika muncul penyimpangan sebagai akibat dari kurangnya pengetahuan (Richards, 1974, Brown, 2007). Kesalahan muncul hanya jika tidak ada niat untuk melakukannya (James dalam Fauziati, 2000). Kesalahan adalah penurunan karena faktor kinerja seperti keterbatasan memori, kelelahan, dan ketegangan emosional. James dalam Fauziati (2000) menyatakan bahwa jika peserta didik mampu mengoreksi suatu kesalahan pada sesuatu yang dikeluarkannya, hal tersebut dapat diasumsikan bahwa bentuk yang dipilihnya merupakan kesalahan.

Dari hasil penelitian ditemukan sekitar 224 kata yang sering salah diucapkan oleh mahasiswa. Berikut adalah kesalahan masingmasing vokal".

Tabel 1. Prosentase kesalahan jumlah vokal

\begin{tabular}{|c|c|c|c|c|c|}
\hline Vokal & terjadi & $\%$ & vokal & terjadi & $\%$ \\
\hline $\mathrm{e}$ & 14 & $5 \%$ & o: & 10 & $75 \%$ \\
\hline U & 9 & $8 \%$ & ауә & 3 & $76 \%$ \\
\hline $\mathrm{p}$ & 14 & $12 \%$ & ขอ & 3 & $85 \%$ \\
\hline I & 58 & $21 \%$ & 3: & 7 & $87 \%$ \\
\hline aI & 21 & $24 \%$ & $\varepsilon \partial$ & 8 & $91 \%$ \\
\hline Іә & 9 & $28 \%$ & $Æ$ & 8 & $100 \%$ \\
\hline ગI & 21 & $31 \%$ & $\Lambda$ & 9 & $100 \%$ \\
\hline$\partial$ & 40 & $34 \%$ & $\partial U$ & 12 & $100 \%$ \\
\hline i: & 16 & $52 \%$ & еІә & 2 & $100 \%$ \\
\hline eI & 16 & $53 \%$ & วІә & 2 & $100 \%$ \\
\hline $\mathrm{u}:$ & 16 & $55 \%$ & әઇә & 1 & $100 \%$ \\
\hline $\mathrm{a}:$ & 14 & $64 \%$ & avə & 1 & $100 \%$ \\
\hline $\mathrm{a} v$ & 11 & $64 \%$ & & & \\
\hline
\end{tabular}

b. Jenis kesalahan dalam pengucapan vokal bahasa Inggris

Penelitian ini menemukan 77 kesalahan dalam pengucapan vokal bahasa Inggris yang dilakukan oleh 20 peserta. Hasilnya menunjukkan peserta melakukan substitusi, penyisipan, dan penghilangan dalam pengucapan yang mereka lakukan. Tabel di bawah ini menunjukkan kasus vokal yang substansinya;

Tabel 2. Kasus kesalahan pengucapan vokal bahasa Inggris (1)

\begin{tabular}{|c|c|c|c|c|}
\hline $\begin{array}{c}\text { Vokal } \\
\text { B.Ing }\end{array}$ & Ket & $\begin{array}{l}\text { Contoh } \\
\text { Kesalah } \\
\text { an }\end{array}$ & $\begin{array}{c}\text { Penguca } \\
\text { pan } \\
\text { benar }\end{array}$ & Ejaan \\
\hline I & $\begin{array}{c}\text { Diganti } \\
\text { denga } \\
\mathrm{n} \text { ə, e, }\end{array}$ & əpi:ld & / opild / & appealed \\
\hline
\end{tabular}


Dinamika Sosial Budaya, Vol 22, No. 2, Desember 2020, pp 272-283

p-ISSN: 1410-9859\& e-ISSN: 2580-8524

http://journals.usm.ac.id/index.php/jdsb

\begin{tabular}{|c|c|c|c|c|}
\hline & $\begin{array}{l}\text { ae, } \\
\text { aI, ey, } \\
\text { e:, dan } \\
\text { i: }\end{array}$ & & & \\
\hline & $\begin{array}{l}\text { Dihilan } \\
\text { gkan }\end{array}$ & smestər & $\begin{array}{c}/ \text { si mest } \\
\partial(\mathrm{r}) /\end{array}$ & semester \\
\hline $\mathrm{E}$ & $\begin{array}{l}\text { Diganti } \\
\text { denga } \\
\mathrm{n} \mathrm{I}, \partial, \\
\text { dan e }\end{array}$ & ekanəmi & $\begin{array}{c}\text { / } \\
\text { I’kanə } \\
\text { mi / }\end{array}$ & economy \\
\hline$\nexists$ & $\begin{array}{l}\text { Diganti } \\
\text { denga } \\
\mathrm{n} \text { e, eI, } \\
\mathrm{a}, \\
\mathrm{e}, \text {, əe, } \\
\text { dan ae }\end{array}$ & $\mathrm{Haz}$ & /hæz/ & has \\
\hline U & $\begin{array}{l}\text { Diganti } \\
\text { denga } \\
\mathrm{n} \quad \mathrm{p}, \\
\mathrm{p} v, \\
\text { dan } \mathrm{u} \text { : }\end{array}$ & stpdənts & $\begin{array}{c}\text { /'stu:də } \\
\text { nts/ }\end{array}$ & students \\
\hline$\partial$ & $\begin{array}{l}\text { Diganti } \\
\text { denga } \\
\mathrm{n} \mathrm{p}, \mathrm{O}, \\
\mathrm{e}, \mathrm{U}, \\
\mathrm{a}, \mathrm{dan} \\
3:\end{array}$ & $\mathrm{pf}$ & /ov/ & of \\
\hline i: & $\begin{array}{l}\text { Diganti } \\
\text { denga } \\
n \text { I, e, } \\
\text { aI, } \\
\text { ae,ay, } \\
\text { dan } \\
\text { ayə }\end{array}$ & It $\int$ & /i:tg/ & each \\
\hline$a:$ & $\begin{array}{l}\text { Diganti } \\
\text { denga } \\
\mathrm{n} \text { a, e, } \\
\text { ə, 3:, } \\
\text { dan I }\end{array}$ & $\begin{array}{l}\text { dpartmə } \\
\mathrm{n}\end{array}$ & $\begin{array}{l}\text { /di'pa:tm } \\
\text { ont/ }\end{array}$ & department \\
\hline o: & $\begin{array}{l}\text { Diganti } \\
\text { denga } \\
\text { n } \mathrm{p}, \mathrm{D}: \\
\text { pu, } \\
\mathrm{a}, \mathrm{a}, \\
\mathrm{a}, \text { dan } \\
\text { ə }\end{array}$ & bpg & /bo:t/ & bought \\
\hline eI & $\begin{array}{l}\text { Diganti } \\
\text { denga } \\
\mathrm{n} \text { e, aI, } \\
\mathrm{I}, \\
\text { dan ae }\end{array}$ & $\begin{array}{l}\text { edokesə } \\
\text { n }\end{array}$ & $\begin{array}{l}\text { /edju'ke } \\
\text { I } \mathrm{n} /\end{array}$ & education \\
\hline aI & $\begin{array}{l}\text { Diganti } \\
\text { denga } \\
\text { n ae, I, }\end{array}$ & Aem & /aim/ & I'm \\
\hline
\end{tabular}

\begin{tabular}{|l|l|l|l|l|}
\hline & $\begin{array}{l}\text { i:, e, } \\
\text { dan } 2\end{array}$ & & & \\
\hline
\end{tabular}

Tabel 3. Kasus kesalahan pengucapan vokal bahasa Inggris (2)

\begin{tabular}{|c|c|c|c|c|}
\hline $\begin{array}{l}\text { Vokal } \\
\text { B.Ing }\end{array}$ & Ket & $\begin{array}{l}\text { Contoh } \\
\text { Kesalah } \\
\text { an }\end{array}$ & $\begin{array}{l}\text { Pengucapan } \\
\text { benar }\end{array}$ & Ejaan \\
\hline OI & $\begin{array}{l}\text { Diganti } \\
\text { dengan } \\
\text { DI, } \mathrm{D}, \\
\text { dan av }\end{array}$ & end3DI & /In'd3oI/ & enjoy \\
\hline Iə & $\begin{array}{l}\text { Diganti } \\
\text { dengan } \\
\text { I, i:, e, } \\
\text { ə, dan 3: }\end{array}$ & rili & /'rioli/ & really \\
\hline$\varepsilon ə$ & $\begin{array}{l}\text { Diganti } \\
\text { dengan } \\
\text { e, e:, eI, } \\
\text { ə, a, aI, } \\
\text { ae, I, i:, } \\
\text { dan Iə }\end{array}$ & wiər & /weə(r)/ & wear \\
\hline аІә & $\begin{array}{l}\text { Diganti } \\
\text { dengan } \\
\text { Ie, Iə, } \\
\text { a:ə, aə, } \\
\text { ae, dan } \\
\text { ayə }\end{array}$ & $\begin{array}{l}\text { epliensi } \\
\mathrm{S}\end{array}$ & /a'plaiənsız/ & $\begin{array}{c}\text { appliance } \\
\mathrm{s}\end{array}$ \\
\hline วІә & $\begin{array}{l}\text { Diganti } \\
\text { dengan } \\
\text { эуə, } \\
\text { эya, } \\
\text { pyə, } \\
\text { pya, } \\
\text { ayə, } \\
\text { pwyə, } \\
\text { awyə, } \\
\text { dan } \\
\text { p:yə }\end{array}$ & ləyəl & /'Һıю1/ & loyal \\
\hline әઇә & $\begin{array}{l}\text { Diganti } \\
\text { dengan } \\
\text { Dwə } \\
\text { dan owə }\end{array}$ & lowər & /'lə凶ə(r)/ & lower \\
\hline aøə & $\begin{array}{l}\text { Diganti } \\
\text { dengan } \\
\text { awə, } \\
\text { pwə, } \\
\text { dan } \mathrm{p} \text { : }\end{array}$ & awər & /avə(r)/ & $\begin{array}{l}\text { our } \\
\text { (st.f.) }\end{array}$ \\
\hline
\end{tabular}


Dinamika Sosial Budaya, Vol 22, No. 2, Desember 2020, pp 272-283

p-ISSN: 1410-9859\& e-ISSN: 2580-8524

http://journals.usm.ac.id/index.php/jdsb

Kesalahan substitusi terjadi hampir $90 \%$ dari seluruh kesalahan pengucapan yang dilakukan oleh responden.

Uraian data hasil penelitian tentang kesalahan vokal dan jenis-jenis kesalahan yang dilakukan oleh partisipan disajikan di bawah ini.

\section{Kesalahan pengucapan vokal bahasa Inggris}

Banyak kesalahan yang dihasilkan oleh peserta dalam mengucapkan vokal bahasa Inggris. Seperti yang telah dijelaskan pada bagian sebelumnya, temuan, peserta melakukan kesalahan pada hampir semua 22 vokal bahasa Inggris dengan persentase yang berbeda-beda. Hal in terjadi karena beberapa faktor.

Bahasa Inggris memiliki ejaan yang sangat kompleks, para peserta memilih pengucapan yang menurut mereka benar tetapi kebanyakan dari mereka tidak tepat dalam penggunaannya. Contoh kasus, kata choose /tfu:z/, kebanyakan mahasiswa mengucapkan /tfuz/, ditemukan pada rekaman pengucapan P01, P03, P05, P09, $\mathrm{P} 10$, dan P11, dan beberapa mahasiswa mengucapkan / t feus /, ditemukan dalam rekaman pengucapan P04. Mereka mungkin merujuk pada kombinasi dua huruf vokal oo yang memiliki kemungkinan pengucapan, / $\mho$ / seperti dalam buku / bok /, dan / u: / seperti dalam makanan / fu:d /.

Selain itu, tidak adanya beberapa vokal bahasa Inggris dari L1, misalnya Bahasa Indonesia yang tidak memiliki vokal panjang; vokal / æ / dan / $\mathrm{\Lambda} /$; diftong / eı /, / ә /, / гә /, / عә /, / шә /, triphthong, menyebabkan kesulitan dalam artikulasi. Masalahnya tidak hanya dalam mengenali dan membedakan suara tetapi juga mengalami kesulitan dalam menghasilkan suara (Syafei, 1988). Para peserta cenderung

untuk menggantinya dengan suara yang mirip dengan L1 mereka, kebanyakan kasus muncul di vokal $/ \Lambda /$ dan $/ \mathfrak{x} /$. Vokal $/ \Lambda /$ memiliki sedikit ciri dan terdengar mirip dengan vokal / a /, seperti pada contoh kata cup dan son diucapkan dengan / kaps /, dan / san /. Vokal / æ / memiliki ciri-ciri kecil yang mirip dengan vokal / e / dan terdengar mirip dengan kombinasi $[\mathrm{a}]$ dan $[\varepsilon]$ untuk orang Indonesia. Sebagai contoh, kata "memiliki" diucapkan sebagai / hez /, terdapat dalam rekaman pengucapan $\mathrm{P} 01, \mathrm{P} 02, \mathrm{P} 06, \mathrm{P} 07$, P08, P09, P10, dan P11, atau / haes /, ada dalam rekaman pengucapan P04, bukan mengucapkan / hæz / yang merupakan ucapan yang tepat.

\section{Jenis kesalahan dalam pengucapan vokal bahasa Inggris}

Berikut ini adalah klasifikasi ketidaktepatan pengucapan yang muncul berdasarkan hasil penelitian;

\section{a) Substitusi (Pengganti)}

Seperti yang sudah dijelaskan sebelumnya, para peserta melakukan pergantian di sebagian besar kasus kesalahan. Beberapa penyebab ketidaktepatan dalam pengucapan diantaranya substitusi yang dilakukan. Dalam penelitian ini diketahui bahwa terdapat empat substitusi yang diklasifikasikan berdasarkan penyebabnya antara lain sebagai berikut;

1) Substitusi intralingual

Tabel di bawah ini menunjukkan vokal yang merupakan substitusi intralingual;

Tabel 4. Substitusi Intralingual

\begin{tabular}{|c|c|c|c|c|}
\hline Vokal & Sub & $\begin{array}{l}\text { Contoh } \\
\text { salah }\end{array}$ & $\begin{array}{c}\text { Ucapan } \\
\text { tepat }\end{array}$ & Ejaan \\
\hline I & ə & ðə & /ðI/ & the(b.v.) \\
\hline$\Lambda$ & $\mathrm{p}$ & ənఐðər & $\begin{array}{c}\text { /ə'n } \Lambda \partial \partial(\mathrm{r} \\
) /\end{array}$ & Another \\
\hline$\partial$ & E & Đer & /ðә(r)/ & there \\
\hline
\end{tabular}


Dinamika Sosial Budaya, Vol 22, No. 2, Desember 2020, pp 272-283

p-ISSN: 1410-9859\& e-ISSN: 2580-8524

http://journals.usm.ac.id/index.php/jdsb

\begin{tabular}{|c|c|c|c|c|}
\hline & U & to & $/ \mathrm{ta} /$ & to (b.c.) \\
\hline & 3: & W3:r & /wə(r)/ & were \\
\hline $\mathrm{a}:$ & E & gered3 & /'gæra:d3 & garage \\
\hline $\mathrm{u}:$ & $U$ & ho & /hu:/ & Who \\
\hline eI & $\mathrm{E}$ & edokesən & 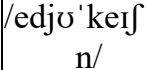 & education \\
\hline$\varepsilon \partial$ & $\mathrm{E}$ & Per & /pعə(r)/ & pair \\
\hline & & wiər & /weə(r)/ & wear \\
\hline$a v$ & $\mathrm{p}$ & $\mathrm{pt}$ & /aut/ & out \\
\hline
\end{tabular}

Vokal / e /, / p /, / ə /, / ひ /, dan diftong / Iə / kemungkinan vokal yang paling bermasalah. Hal ini terjadi karena ketidakcocokan pengucapan ejaan bahasa Inggris. Kurangnya pengetahuan adalah alasan utama para peserta menghadapi begitu banyak ketidaktepatan dalam pengucapan.

Tabel di atas menunjukkan bahwa vokal / ə /, / a: /, / ei /, dan / عə / digeneralisasikan menjadi / e /. Dengan menggeneralisasi ejaan huruf 'a' pada kata seperti 'education' / edju'kerfn / dan yang kedua 'a' di 'garage' / 'gæra:dz / as / edvkesən / dan / geredz / dalam merujuk 'a' pada kata seperti ' banyak '/ meni /. Huruf 'e' dalam kata seperti 'there' / ðә (r) / diucapkan dengan ucapan / der / yang merujuk kata seperti else / els /. Seperti halnya kombinasi ejaan 'ai', pada kata seperti 'pair' / peə (r) / diucapkan dengan / per / yang digeneralisasikan dalam merujuk 'ai' pada kata seperti 'again' / o'gen /.

Vokal / $\Lambda$ /, / əu / dan / av / digeneralisasikan menjadi / $\mathrm{p} /$. Kata-kata seperti 'another' / ə'nıðə (r) / diucapkan dengan / ənெðər / yang menggeneralisasi ejaan huruf 'o' dalam merujuk kata seperti 'got' / gpt / dan ejaan kombinasi dari 'ou' in 'out' / aot / diucapkan sebagai / pt / dalam merujuk kata seperti 'batuk' / kpf /. / Eə / dan / aı / digeneralisasikan menjadi / гə /. Kata seperti 'wear' / weə (r) / diucapkan dengan / wiər / yang menggeneralisasi kombinasi ejaan 'ea' dalam kata seperti 'idea' / aı' dıə /.

Selanjutnya pada kasus / ə /, terdapat substitusi interlingual dan substitusi vokal pada beberapa kata yang memiliki ketentuan pengucapannya. Sebagian besar peserta tidak mempermasalahkan kondisi ini. Mereka kebanyakan mengucapkannya seperti yang biasa diucapkan. Kata 'the' / ðə / yang muncul sebelum konsonan akan berbeda pelafalannya dengan 'the' / ðı / yang muncul sebelum vokal. Selain itu, kebanyakan kata yang memiliki bentuk lemah akan mengalami perbedaan pengucapan dengan bentuk kuat atau bentuk lainnya. Misalnya seperti yang terlihat pada tabel di atas, kata tersebut diucapkan sebagai /w3:r/ bila bunyi lemah, maka diucapkan sebagai / wə (r) /.

2) Substitusi Interlingual

Tabel di bawah ini menampilkan vokal yang merupakan substitusi interlingual;

Tabel 5. Substitusi Interlingual

\begin{tabular}{|c|c|c|c|c|}
\hline Vokal & $\begin{array}{c}\mathbf{S} \\
\mathbf{u b}\end{array}$ & $\begin{array}{c}\text { Contoh } \\
\text { salah }\end{array}$ & $\begin{array}{c}\text { Ucapan } \\
\text { tepat }\end{array}$ & Ejaan \\
\hline I & E & endzDI & /In'dzoi/ & Enjoy \\
\hline$\Lambda$ & U & junusuəl & / ^n'ju:3l & unusual \\
\hline \multirow[t]{2}{*}{$\nexists$} & A & Hay & /hæy/ & Hang \\
\hline & $\mathrm{E}$ & Hed & /hæd/ & $\begin{array}{l}\text { had } \\
\text { (st.f.) }\end{array}$ \\
\hline i: & I & It $\int$ & /i:t $f /$ & Each \\
\hline$a:$ & A & lard3 & /la:dz/ & Large \\
\hline O: & $\mathrm{p}$ & mpr & /mo:(r)/ & More \\
\hline aI & $\mathrm{Ae}$ & Aem & /aIm/ & I'm \\
\hline OI & DI & endzDI & /In'dzoI/ & Enjoy \\
\hline Iə & I & rili & /'rioli/ & Really \\
\hline$\varepsilon ə$ & E & Đer & /ðعә(r)/ & $\begin{array}{l}\text { there } \\
\text { (st.f.) }\end{array}$ \\
\hline$\partial \mho$ & 0 & So & /səu/ & So \\
\hline aひə & awə & awər & /aøə(r)/ & $\begin{array}{c}\text { our } \\
\text { (st.f.) }\end{array}$ \\
\hline
\end{tabular}

Kasus ini termasuk substitusi interlingual yang dianggap sebagai substitusi Indonesia atau bahkan Jawa. Pengaruh sistem 
Dinamika Sosial Budaya, Vol 22, No. 2, Desember 2020, pp 272-283

p-ISSN: 1410-9859\& e-ISSN: 2580-8524

http://journals.usm.ac.id/index.php/jdsb

ejaan bahasa sebelumnya akan mempengaruhi substitusi ini. Seperti kita ketahui bahwa ada hubungan antara ejaan dan artikulasi bahasa peserta sebelumnya. Selain itu, sebagian besar vokal pengganti, / $\mathrm{\Lambda} /, / \mathfrak{x}$ /, / i: /, / u: /, / a: /, / o: /, / з: /, / rə/, / عə/, / əə /, dan / avə / / əชə / / эю /, tidak dikenal di sistem bahasa sebelumnya. Para peserta cenderung mengucapkan kata-kata anggapan sebagai bahasa sebelumnya.

Para peserta melakukan ejaan pada suara bunyi dalam melafalkan huruf vokal. Itu terjadi dalam kata seperti 'nikmati', 'bangga', 'milik kita', dan 'rendah'. Huruf 'e' dalam 'nikmati' / In'dzor / diucapkan sebagai / endżi /. Vokal bahasa Indonesia / e / tidak diragukan lagi mewakili huruf 'e'. Selain 'cought' dan 'proud', vokal yang merepresentasikan 'au' dan 'ou' diucapkan sesuai dengan sistem ejaan bahasa Indonesia. Keduanya dilafalkan sebagai diftong. Dalam sistem ejaan bahasa Indonesia, kombinasi huruf 'au' diucapkan sebagai / av /. Sedangkan 'ou' memiliki kasus yang berbeda. Meskipun jarang dan tidak diketahui, dilafalkan sebagai / pu / yang merupakan huruf yang dipengaruhi oleh sistem ejaan bahasa Indonesia.

3) Substitusi lintas bahasa (crosslingual)

Tabel di bawah ini menampilkan vokal yang didukung substitusi lintas bahasa;

Tabel 6. Crosslingual substitution

\begin{tabular}{|c|c|c|c|c|}
\hline Vokal & Sub & $\begin{array}{l}\text { Contoh } \\
\text { salah }\end{array}$ & $\begin{array}{c}\text { Ucapan } \\
\text { tepat }\end{array}$ & Ejaan \\
\hline I & $\mathrm{e}$ & elektrıkəl & /I'lektrıkl/ & Electrical \\
\hline$\partial$ & $\mathrm{p}$ & pf & /əv/ & Of \\
\hline $\mathrm{u}:$ & v & anjusuəl & /^n'ju:zl/ & unusual \\
\hline o: & $\mathrm{p}$ & bpg & /bo:t/ & bought \\
\hline
\end{tabular}

Seperti yang ditunjukkan pada tabel di atas, kasusnya adalah substitusi lintas bahasa. Substitusi ini, sebagaimana dijelaskan sebelumnya, mengacu pada kesalahan ambigu yang tidak jelas apakah disebabkan oleh pengaruh bahasa target atau sistem bahasa sebelumnya.

Pada huruf 'e', dalam merepresentasikan pengucapannya, peserta terlihat menggunakan vokal / e /, yang sering digunakan dalam bahasa Inggris atau bahasa Indonesia. Contohnya adalah kesalahan pengucapan kata elektrik yang dilafalkan / elektrrkəl / bukan / I'lektrikl /. Para peserta juga terlihat menggunakan vokal / ə /. Sehubungan dengan itu bahasa Inggris menggunakan vokal untuk mewakili pengucapan huruf 'e', serta Bahasa Indonesia. Meski seringkali kurang dalam bahasa Inggris, lagi-lagi hal itu berpengaruh pada pengucapan peserta. Selain itu, hal ini juga terjadi pada huruf 'o' yang diucapkan / $\mathrm{p} /$ dan 'u' yang diucapkan / $\mho /$. Substansi kesalahan tidak jelas apakah itu justru dipengaruhi oleh bahasa ibu atau bahasa target.

\section{b) Sisipan}

Tabel di bawah ini menampilkan vokal yang didukung untuk penyisipan;

Tabel 7. Sisipan

\begin{tabular}{|c|c|c|l|}
\hline $\begin{array}{l}\text { Vokal yang } \\
\text { disisipkan }\end{array}$ & kesalahan & Yang tepat & Ejaan \\
\hline$\partial$ & parpəl & $/$ 'p3:pl/ & purple \\
\hline I & IS & $/ \mathrm{z} /$ & is \\
\hline Uə & anjusoəl & $/ \Lambda \mathrm{n}$ 'ju:zl/ & unusual \\
\hline $\mathrm{E}$ & kərtens & $/$ 'k3:(r)tnz/ & curtains \\
\hline eI & kərtens & $/$ 'k3:(r)tnz/ & curtains \\
\hline
\end{tabular}

Vokal yang ditampilkan pada tabel di atas paling banyak disisipkan oleh peserta. Penyisipan sebagian besar dipengaruhi oleh bahasa peserta sebelumnya. Sistem bahasa yang mengenali ejaan menjadi bunyi dan menolak satu atau lebih konsonan dalam satu waktu, yang membuat kata-kata tersebut kesulitan untuk diucapkan. Mereka tampaknya memasukkan vokal bantuan 
Dinamika Sosial Budaya, Vol 22, No. 2, Desember 2020, pp 272-283

p-ISSN: 1410-9859\& e-ISSN: 2580-8524

http://journals.usm.ac.id/index.php/jdsb

untuk membantu mereka mengucapkan. Misalnya, penyisipan / a / pada kata 'ungu' diucapkan sebagai / parpəl / bukan / 'p3:pl /. Selain itu, kata siswa / 'stju:dnt / dan diberi / 'givn / diucapkan sebagai / 'stodent / dan / 'gifən /, ini adalah kasus di mana semuanya mencoba melakukan ejaan satu per satu. Terkadang hal itu menimbulkan suara tambahan, seperti pada / 'Woznt / dan department / di'pa:tmənt / diucapkan sebagai / 'Wosən / dan / də'partəmen /. Vokal / a / biasa digunakan untuk menambah atau menyisipkan yang dilakukan oleh peserta.

\section{c) Penghilangan}

Tabel di bawah ini menampilkan vokal yang didukung oleh penghilangan;

Tabel 8. Penghilangan

\begin{tabular}{|c|c|c|c|}
\hline Vokal & Kessalahan & $\begin{array}{c}\text { Yang } \\
\text { tepat }\end{array}$ & Ejaan \\
\hline I & smestər & $/$ sI'mestə(r)/ & Semester \\
\hline
\end{tabular}

$$
\text { Para peserta tampaknya }
$$

menghilangkan / I / pada kata 'semester' / si'mestə (r) / yang dilafalkan / smestər /. Hal ini terjadi karena adanya gangguan kata 'semester' / séméster / dalam bahasa, yang disebut Muslich, zeroisasi dan dilafalkan / smestər / atau / sméster /. Istilah yang digunakan untuk hilangnya suara sebagai akibat dari upaya penghematan pengucapan (Muslich, 2008).

\section{KESIMPULAN}

Bunyi yang menjadi kesalahan pengucapan vokal bahasa Inggris mahasiswa di beberapa fakultas di Universitas Semarang adalah / i: /, / I /, / U/, / u: /, / e /, / a /, / 3: /, /

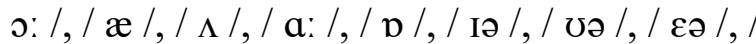

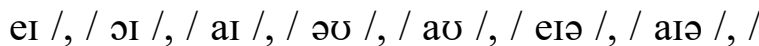
эю /, / әуә /, / ауә /. Vokal yang paling bermasalah adalah, vokal / $\Lambda$ / seperti keberuntungan / $1 \Lambda \mathrm{k} /$, vokal / æ / seperti pada
/ ðæt /, diftong / əu / seperti pada old / əold /, tripthong / егə / seperti pada layer / leıə (r) /, triphtong / эг / seperti pada loyal / lorə /, triphthong / ə৩ə / seperti pada lower / ləvə (r) /, dan triphthong / avə / seperti pada jam / avo (r) / yang memiliki hampir 100\% kesalahan pengucapan.

Jenis kesalahan yang terjadi dalam pengucapan vokal bahasa Inggris pada kesalahan substitusi, kesalahan sispan, dan kesalahan penghilangan.

\section{SARAN}

Bagi peneliti, karena penelitian ini masih kurang banyak hal dan jauh dari kesempurnaan serta terdapat faktor lain yang mempengaruhi pengucapan mahasiswa, maka peneliti berharap ada peneliti lain yang akan menyelidiki faktor-faktor lain yang berhubungan dengan pengucapan bahasa Inggris. Peneliti juga berharap penelitian ini bermanfaat dan dapat dijadikan acuan bagi pihak lain yang akan melakukan dan mengembangkan penelitian yang serupa.

Para mahasiswa disarankan untuk memperhatikan pembelajaran bahasa Inggris, terutama dalam pengucapan, untuk meningkatkan kompetensi mereka dalam berbicara. Dengan penelitian ini mahasiswa juga harus menyadari kesalahan yang mereka hadapi dan berusaha untuk mengatasi masalah atau kesulitan yang mereka hadapi.

\section{DAFTAR PUSTAKA}

Arikunto, Suharsimi. 2006. Prosedure Penelitian: Suatu Pendekatan Praktik. Jakarta: PT Rineka Cipta.

Brown, H. Douglas. 1994. Principles of Language Learning and Teaching ( $3^{\text {th }}$ ed.). USA: Prentice Hall. 
Dinamika Sosial Budaya, Vol 22, No. 2, Desember 2020, pp 272-283

p-ISSN: 1410-9859\& e-ISSN: 2580-8524

http://journals.usm.ac.id/index.php/jdsb

Budiasih. 2013. English Pronunciation Practice. Surakarta: Fataba Press. Corder, S. Pit. 1973. Introducing Applied Linguistics.

Harmondsword: Penguin.

Creswell, John W. 2012. Educational Research: Planning, Conducting, and Evaluating Quantitative and Qualitative Research ( $4^{\text {th }}$ ed.). Boston: Pearson Education. Inc.

Cruttenden, Alan. 2008. Gimson's Pronunciation of English ( $7^{\text {th }}$ ed.). London: Hodder Education.

Crystal, David. 1985. A Dictionary of Linguistics and Phonetics ( $2^{\text {nd }}$ ed.). New York: Basil Blackwell.

Crystal, David. 2004. The Cambridge Encyclopedia of the English Language.London:Cambridge University Press.

Dalton C, and Seidlhofer, B. 1994.Pronunciation. Oxford: Oxford University Press.

Echols, Jhon M., Sadily, Hasan. 2003. An Indonesian-English Dictionary ( $3^{\text {th }}$ ed.). Jakarta: Gramedia Pustaka Utama.

Ellis, R. 1994. The Study of Second Language Acquisition. Oxford: Oxford University Press.

Fatimah, Siti. 2010. Pronunciation Problem of English Segmental Sound among the First Graders of SMA Islam Malang. Thesis. Malang: Malang University.
Fauziati, Endang. 2000. Reading on Applied Linguistics: A Handbook for Language Teacher and Teacher Researcher. Surakarta: Era PustakaUtama.

Kelly, Gerald. 2001. How to Teach Pronunciation. England: Longman.

Kristina, Diah and Rarasteja, Zita. 2006. Pronunciation 1. Surakarta: Sebelas Maret University Press. Mathew, Ingrid Brita D. 1997. Error in Pronunciation of Consonants by Indonesian, Gayo and Acehnese Learners of English as a Foreign Language.Thesis. Perth: Edith Cowan University.

Moleong, Lexy. 2002. Metodologi Penelitian Kualitatif. Bandung: Remaja Rosdakarya.

Pennington, Martha C. 1996. Phonology in English Language Teaching: An International Approach. New York: Longman.

Steinhauer, Hein. 2000. Indonesian and Regional Language in Indonesia. In Kajian Serba Linguistik: untuk Anton Moeliono Pereksa Bahasa (pp.175-195). Jakarta: Gunung Mulia

Sutopo, H. B. 2006. Metodologi penelitian kualitatif. Surakarta: Universitas Sebelas Maret Surakarta.

Syafei, Anas. 1988. English Pronunciation: Theory and Practice. Jakarta: Departement Pendidikan dan Kebudayaan. 
Dinamika Sosial Budaya, Vol 22, No. 2, Desember 2020, pp 272-283 p-ISSN: 1410-9859\& e-ISSN: 2580-8524

http://journals.usm.ac.id/index.php/jdsb 